\title{
Why don't governments need trade unions anymore? The death of social pacts in Ireland and Italy
}

\section{Pepper D. Culpepper ${ }^{1, *}$ and Aidan Regan ${ }^{2}$}

${ }^{1}$ Department of Social and Political Science, European University Institute, San Domenico di Fiesole, Italy;

${ }^{2}$ Department of Politics and International Relations, University College Dublin (UCD), Ireland

*Correspondence: pepper.culpepper@eui.eu

During the 1990s, a prominent strategy of economic adjustment to the challenges of competitiveness and budgetary retrenchment among the non-corporatist countries of Europe was the negotiation of social pacts. Since the onset of the great recession and the Eurozone crisis, social pacts have been conspicuous by their absence. Why have unions not been invited into government buildings to negotiate paths of economic adjustment in the countries hardest hit by the crisis? Drawing on empirical experiences from Ireland and Italy — two cases on which much of the social pact literature concentrated - this article attributes the exclusion of unions to their declining legitimacy. Unions in the new European periphery have lost the capacity either to threaten governments with the stick of protest or to seduce policymakers with the carrot of problem-solving. They are now seen as a narrow interest group like any other.

Keywords: industrial relations, political economy, public policy, trade unions, tripartite institutions, Europe

JEL classification: J51 trade unions, J58 public policy, P16 political economy

The deep practice of concertation in the past caused the evils against which we are fighting today, and on the basis of which our children and grandchildren do not easily find work. [Unions and employers] should not be actors to which public authorities outsource their political responsibility.

Mario Monti, Italian Prime Minister, July 2012

The Department of Finance has concluded that the dominance of the social partnership process did enormous damage to our financial system. This is something I intend to fix.

Brian Lenihan, Irish Minister of Finance, December 2010 


\section{Introduction}

One of the defining features of the politics of adjustment to the Economic and Monetary Union (EMU) and domestic welfare reforms throughout the 1990s and early 2000 s was the negotiation of social pacts among governments, unions and employers. This process of negotiated reform took place in various European countries as a response to different problems. Centralized corporatist deals in some countries embedded social partnership in the politics of industrial relations, while in others social pacts were one-shot negotiations aimed at labour market flexibilization, wage restraint and social policy reform (Rhodes, 1998). Ireland and Southern European countries such as Italy and Spain stood out in the literature because they did not have the embedded collective bargaining arrangements characteristic of coordinated market economies (CMEs), in which governments engaged routinely with unions in policy concertation. Scholars who observed these processes found that they were adopted by weak governments that needed the support of the social partners in order to adopt difficult political reforms (Baccaro and Lim, 2007; Baccaro and Simoni, 2008; Avdagic, 2010).

Prior to the 'great recession', the process of involving organized labour in the making of social pacts was conceived as one of the most likely strategies for successfully mobilizing societal support for challenging reforms, even in countries without a history of corporatist concertation. In the past 5 years, however, trade unions have been notable by their absence from reform initiatives (Armingeon and Baccaro, 2012). National governments, regardless of partisanship, have actively rejected a process of negotiated adjustment that includes unions. Furthermore, the core actors of the Eurozone are encouraging member-states to establish governments capable of acting without trade union support.

In this article, we return to two of the cases that were central to the literature on social pacts: Ireland and Italy. We argue that 'social partnership' has collapsed because trade unions in these countries now have nothing to offer to policymakers: they cannot strike fear into the heart of a government or employers through industrial action; and they cannot develop and sell broad reforms to their members. In fact their narrow membership compels them to pursue strategies that favour insiders, not outsiders. Unions have neither the carrots with which to attract governments to incorporate them into policymaking nor the sticks with which to compel their inclusion.

Social pacts were once the intersection between the system of public policymaking and the system of interest representation. But while governments still need a way to mobilize the populace behind policies that involve hard choices, many union confederations no longer have the power to make themselves that interlocutor, nor the capacity to figure out something governments cannot do on their own. Part of this failure, we argue, is due to an inability to be able to 
offer something to employers, once the privileged partners of unions in these negotiations. Thus, part of the story of the decline of government-led social pacts is a decline in the perception of employers about the desirability of these arrangements. Yet our research design allows us to cast doubt on a hypothesis derived from differences in varieties of capitalism: Italy (particularly its northern half) is often categorized as a CME, while Ireland is a liberal market economy (LME). Thus, the variation we observe is not across types of capitalism, but within both types over time. Italy in the 1990s incorporated unions in its major reforms; today it does not. Ireland in the 1980, 1990 and 2000s incorporated unions into a structured form of social partnership; now decisions are made only with public-sector unions. What has changed over time is not the type of capitalism, but the capacities of unions and their consequent public standing in both countries.

Our findings follow the argument developed by Baccaro and Howell (2011), that there has been a neoliberal trend in systems of industrial relations. But our empirical focus is on tripartite policymaking, not on industrial relations institutions. Thus, the power resource emphasized by Baccaro and Howell, workplace mobilization, is only part of the story of why unions are excluded. They also have nothing to offer to solve government's problems, such as restraining wages or passing pension reforms. Without any ability to solve these problems-by developing innovative solutions or selling them to an increasingly narrow membership-unions are merely another interest group trying to preserve their special benefits.

Our argument proceeds as follows. First, we show that existing accounts cannot explain the differences we observe. Instead, we develop an argument about both the carrot (mobilizing consent) and the stick (strikes) on which trade unions used to draw. We then show through process-tracing of the two cases that both capacities were in evidence in the early period but absent in the second period, and how this influenced government choices about incorporating unions into policymaking. A final section considers the limits and further implications of our findings.

\section{Social pacts and government response to crisis}

Before looking at the capacities of unions in detail, it is worth reviewing some alternative explanations that could account for the change in government strategy regarding negotiation with the social partners. First, the crisis facing national governments in the EMU may be so big that it excludes the possibility of a negotiated adjustment through encompassing social pacts. This claim is ironic, given that much of the literature on social pacts in the 1990s focused on their necessity for governments under severe pressure to meet the original EMU criteria and stabilize their finances while introducing disinflation (Hancké and Rhodes, 2005; Hassel, 2006; Avdagic, 2010). Wage and labour market flexibility, central to all social pact 
agreements over the past 25 years, are the two remaining policy instruments available to national governments in the absence of exchange and interest rate adjustments. Thus, in the Eurozone, member-states now have an incentive to simulate an internal devaluation. Renationalizing these policies through a centralized social pact agreement would in theory send a positive signal to international markets and reflect the policy preference of core Eurozone actors that national competitiveness is the only solution to a balance of trade crisis for deficit countries. Hence, the international crisis, in the context of Eurozone constraints and increased uncertainty should be more — not less — of an incentive for national governments to adopt a negotiated process of adjustment with trade unions.

Second, it could be argued that even if the international crisis acts as an incentive to renationalize social pact arrangements, the EU transnational response to the financial crisis rules out this strategy. The sovereign debt crisis has put unprecedented pressure on the fiscal capacity of some states. For the hardest hit countries in the Eurozone-Greece, Ireland, Portugal, Italy and Spain-much of the policy response has been almost entirely dictated by the ECB and IMF. Therefore, coordination has shifted away from the national to the transnational level, ruling out a strategy of social pacting with national trade unions. In this regard 'Europe', rather than 'social pacts', justifies the government strategy.

But this claim ignores a key insight of the social pact literature: that weak governments need to rely on the legitimation of social pacts in order to push through hard reforms in difficult times (Baccaro and Lim, 2007; Baccaro and Simoni, 2008; Avdagic, 2010). Ireland and Italy, like the rest of the newly 'peripheral' countries of the Eurozone, were characterized by extraordinarily weak governments during the period of adjustment. And this adjustment was expected by international actors to be developed nationally. Even in Greece, which was under the most intense fiscal pressure, international creditors were still responsive to national protests and deferred to national policy designs (Psimitis, 2011). The severity of the crisis and its internationally coordinated response, while narrowing the domestic policy menu, did not rule out the possibility of social pacts.

Third, one could argue that the underlying policy bargain of social pacts, as they evolved during the neoliberal era, primarily benefited the material interests of employers (Hassel, 2009) or the electoral interests of governments (Hamann and Kelly, 2007). Much like the cross-class coalitions underpinning CMEs, the underlying agreement was on the introduction of market-friendly reforms (Regini, 2000). In this sense national social pacts were facilitated by government, but the main interests driving the process were those of export employers. It could be argued that governments have changed strategy because employers no longer have anything to gain from negotiating centralized pacts with trade unions. They would prefer to adopt a market-clearing strategy of adjustment at the firm level. 
This theoretical posture ignores the fundamental fact that the main actors striking deals in social pacts are national governments, which have an interest in ensuring political stability in the economy. Social pacts supplement the electoral mandate of government by involving organized interests with the disruptive capacity to veto change in a process of negotiated reform (Baccaro and Simoni, 2008). Involving trade unions as social partners contributed towards political stability and the strategic management of the economy. The nature of that bargain, and the type of trade-offs involved in this exchange certainly changed over time, particularly during the neoliberal era, but the core actors did not. It is a relationship between national governments and trade union confederations.

We contend that it is not the Eurozone crisis, weak government or employer interests per se that explain the collapse of social pacting, but the weakness of trade unions themselves. Our core argument is that unions in the private sector cannot impose harm on employers or government, and their narrow membership and weak organizational capacities do not allow them to develop innovative solutions or the ability to mobilize support for a broad set of reforms that would benefit the workforce at large. So the state gains little by including them in a tripartite process of adjustment (outside the public sector), and hence they cannot force their way to the bargaining table.

\subsection{Neither carrots nor sticks: what unions can no longer do}

The absence of social pacts from the policy repertoire of any of the states facing the Eurozone crisis could be called the product of the incredible shrinking union movement. We do not mean this in the sense merely of the declining density of the workforce that is unionized, although that represents one of the problems facing the union movement in peripheral Eurozone economies. The social pacts of the 1990s emerged from a situation in which the government needed unions to help design, implement and mobilize support for reforms of the labour market, fiscal and social policy. Because unions could cause governments to fall, they were veto players in reforms (Natali and Rhodes, 2004; Baccaro and Simoni, 2008). The assent of unions to new policies, and the mobilization of their members on behalf of these reforms, could prove the difference between a reform's success and its failure (Culpepper, 2002). This veto power was the stick, and this mobilization capacity the carrot, that unions could lay before state policymakers to induce their inclusion in reform processes. These were the legitimating macro-capacities of unions, divorced from any of the micro-level (firm-based) coordination characteristic of CMEs with a long history of negotiated adjustment (Hancké and Rhodes, 2005). And they were the capacities that made unions indispensable players in the process of reform for weak governments facing severe economic and social challenges. 
In the cases that defined the social pact literature, and which now find themselves at the heart of the Eurozone crisis-Ireland, Italy, Portugal and Spain — these twin capacities were crucial aspects of the involvement of unions in the making of social pacts. Although we divide them analytically into the carrot and the stick, both the threat and the mobilizing capacity of unions in these countries were products of the same underlying property: an ability to speak for the workforce collectively. On the threat side, unionized workers could choose to strike, bringing enterprises and tightly coupled supply chains to a halt. But their strikes could also spill over into general protests, in which they would speak as tribunes of the populace against the excessive accommodation of government to demands of liberalization and austerity. This is a threat that employers once feared, because of the costs; and that politicians once dreaded, because of the instability and subsequent lost votes they could create.

The same ability to speak for the broad constituency of working people also underlay the ability to convince parts of the population to accept unpopular reforms. Part of this was a product of having a broad membership and knowing how to count votes in that membership. That is, knowing how to develop reform policies that could be sold to your members. This capacity involved targeting reforms in a way that shielded members who could bring down agreements from the harshest reforms (Simoni, 2010). But it also involved developing strategies to justify those reforms within a broad part of the workforce (Baccaro, 2002). These two capacities were inextricable. And together, they comprised a powerful incentive for governments to work with unions to mobilize active consent for difficult reforms to a group that was inherently distrustful of those reforms.

There is a clear reason that governments during the 1990s struck social pacts with unions: unions were not merely another interest group. They were speaking as the representatives of all those who depend on working for a living, whoever they voted for. This legitimacy allowed even weakened unions to be uniquely capable negotiating partners for government. Analysis that focuses only on the declining market power of unions sees the loss of the stick, but fails to include the loss of the carrot (Baccaro and Howell, 2011). And carrots can look pretty appetizing to shaky governments being asked to implement unpopular austerity packages. As displayed in Table 1, the carrot and the stick have roots in both the workplace and on the streets.

Unions do not lose these twin capacities of threat and of mobilizational capacity merely as a result of falling membership. We argue that both the carrot and the stick depend on union legitimacy: that is, the recognition in elite and mass opinion that unions speak as the privileged representative of working people. It is true that a fall in union density or a decline of collective bargaining coverage should reduce union legitimacy, other things being equal. Defending insider privileges while labour market outsiders get a much worse deal probably does undermine union legitimacy 
Table 1 Trade union capacities: the carrot and the stick

\begin{tabular}{lll}
\hline & Firm-level & Polity-level \\
\hline $\begin{array}{l}\text { Carrot } \\
\text { Stick }\end{array}$ & $\begin{array}{ll}\text { Mobilize consent } \\
\text { Industrial action }\end{array}$ & $\begin{array}{l}\text { Problem-solving } \\
\text { Mass protests }\end{array}$ \\
\hline
\end{tabular}

over time (Palier and Thelen, 2010), and we suspect the narrowing of union membership across age cohorts is one root cause of this declining legitimacy.

Yet French unions, which long boasted density below even that of the USA, were nevertheless key actors in mobilizing social opposition to unilateral reforms during the 1990s (Natali and Rhodes, 2004). And in Italy, many of the reforms of the 1990s were based on unions using their role in negotiations to protect the narrow rights of their existing members; nevertheless, the participation of Italian unions in social pacts reinforced rather than undermined the raison d'être of the union movement, at least among its own members (Baccaro, 2002; Simoni, 2010). Even with declining membership, it is possible for unions to stake out positions that require them to make trade-offs publicly on behalf, not just of their members, but also of the working people who may not be in unions. This capacity, we argue, underpins the special privileges accorded to unions by state policymakers.

Public opinion data can shed some light on the perception of unions currently and in the recent past. Figure 1 portrays public perceptions towards the legitimacy of trade unions (operationalized as 'public distrust toward' unions). ${ }^{1}$ Eurobarometer only began asking the question about distrust in unions from 1997, and thus the data series misses the crucial periods in which we are interested, when social pacts began in Ireland (in 1987) and in Italy (in the early 1990s). In Italy, distrust in unions has been consistently high since 1997, which coincides with the ebbing support for social pacting after the three big pacts of 1992, 1993 and 1995 (Molina and Rhodes, 2007). ${ }^{2}$ However, we do not have a measure of change in Italy, so we do not know the extent of distrust of unions before 1997. The Irish case, however, is clear-cut: distrust in unions was low during the 'Celtic Tiger' period of social partnership, but increased rapidly from 30 to 53\% after 2007,

\footnotetext{
${ }^{1}$ Eurobarometer asks the following question: 'I would like to ask you a question about how much trust you have in certain institutions. For each of the following institutions, please tell me if you tend to trust it or tend not to trust it'. We summarize the answers for 'tend not to trust' trade unions as distrust in trade unions.

${ }^{2}$ Eurobarometer appears to have asked the question nine times between 1997 and 2010, and neither before nor since (as of this writing in 2013). In the figures shown, we exclude the data for Italy in 2001, because the number for distrust deviated from all other years, almost entirely to the benefit of 'don't know' answers (not in favour of 'tend to trust' answers, as one would normally observe with a decrease in distrust).
} 


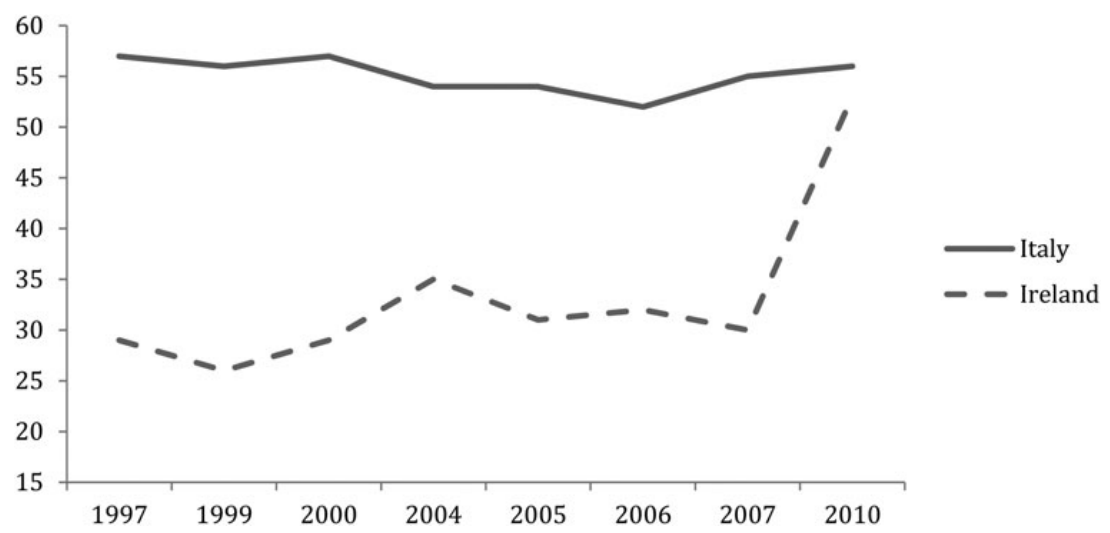

Figure 1 Levels of distrust in Trade Unions in Ireland and Italy. Source: Eurobarometer 1997-2010.

when social partnership turned into a specific public-sector deal. By 2010, the levels of public distrust towards unions had converged in the two countries, with $53 \%$ of Irish and $56 \%$ of Italian respondents saying they tended not to trust trade unions.

The same trend of growing distrust can also be observed in the other crisis-afflicted countries of the Eurozone, which had previously used social pacts to negotiate adjustment to EMU: in 2010, the five newly peripheral economies of western Europe (Greece, Ireland, Italy, Portugal and Spain) had an average distrust towards unions of $57 \%$ of the population, as opposed to $37 \%$ in those western members of the European Union typically counted as CMEs. ${ }^{3}$ These data speak against a potential alternative hypothesis that union distrust is primarily the result of having signed social pacts in the past. Greece, with no history of social pacts, featured the highest level of union distrust in our 2010 sample, at 65\%. In Finland, which relied heavily on social pacting in earlier years, public distrust towards unions registered a mere 27\%-the lowest in the 2010 sample. Figure 2 displays the data on union distrust for the five CMEs of the Eurozone, which we call the core, against the five peripheral economies.

The convergence of high distrust in unions in the countries of the European periphery and its substantially lower average level across the CMEs of the Eurozone cannot only be explained by the observation that there is a decline in collective bargaining and industrial action across the advanced industrial countries (Baccaro and Howell, 2011, pp. 528-529). The decline in legitimacy is not just about the declining market power of unions, but also about their ability to partner with the state and employers in the provision of macroeconomic solutions to complex problems. This problem-solving may take the guise of wage restraint, or it may take the guise of

\footnotetext{
${ }^{3}$ Austria, Belgium, Finland, Germany and the Netherlands.
} 


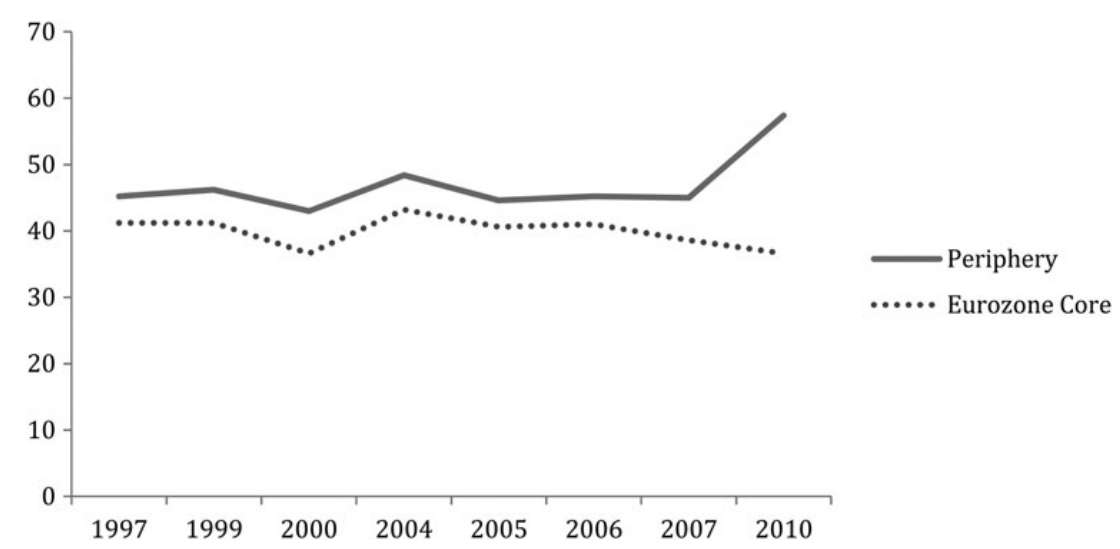

Figure 2 Levels of distrust in Trade Unions in Eurozone Core and Periphery. Source: Eurobarometer 1997-2010. Periphery includes Greece, Ireland, Italy, Portugal, and Spain; Eurozone core includes Austria, Belgium, Finland, Germany, and the Netherlands.

developing acceptable policy solutions to retrench social rights. When unions are able to negotiate such deals, bringing their membership along and defending the reform to a wider public, they burnish their own credentials to be special partners of the state, whether they represent 20 or $50 \%$ of the workforce. But when they are unable, or unwilling, to take such a role at time $t$, they make it more difficult for themselves to play such a role at $t+1$. By not bolstering their public legitimacy, they undercut their own capacity to be privileged interlocutors of the state.

The next two sections of this paper examine the beginning and the end of social pacting as a form of policymaking in Ireland and Italy. Considering these propositions in the Irish and Italian cases has several methodological advantages. First, it contrasts the two most discussed cases of social pacts, which are institutionally diverse. Italy, though heterogeneous, has sometimes been classified among the CMEs of Europe; Ireland is an LME (Hall and Soskice, 2001). Within the social pact literature, scholars have pointed to different levels of firm-level arrangements differentiating the Italian case from the Irish case (Hancké and Rhodes, 2005). Finally, different economic problem loads have been said to characterize the Italian and Irish social pacts (Avdagic, 2010). Across these differences, we will show, union capacities (carrot and stick) showed a remarkably similar development, and they had a similar impact on the emergence and later disappearance of social pacts in the former poster children of negotiated reform in the EMU.

\section{The rise and fall of social partnership in Ireland}

The core economic problem facing successive Irish governments throughout the 1980s was minimizing strikes and controlling wage-inflation (Murphy and 
Hogan, 2008). During this period Ireland returned to firm-level wage bargaining after the failure of three previous attempts to centralize industrial relations in the late 1970s (Hardiman, 1988). The rise in inflation was widely attributed to individual trade unions using their collective bargaining strength at the shop-floor level to push up wages at the expense of competitiveness; a policy continued throughout the 1980s, despite the unemployment crisis. It proved to be counterproductive when an internal report by the Irish Congress of Trade Unions (ICTU) found that their members had negotiated a 73\% increase in nominal wages from 1980 to 1986 , but real take home pay had declined by $7 \%$. A combination of increases in income tax and inflation removed any wage gains trade unions had made. This led a newly emergent trade union leadership in ICTU to recognize that coordinated wage restraint was in the collective interest of society if employers invested the surplus profit in employment (Regan, 2012). For Irish unions, giving up their disruptive capacity was contingent on having access to influence government budgetary policy.

From 1981 to 1986 the centrist Fine Gael-Labour government actively excluded trade unions from policymaking and promoted decentralized industrial relations. This meant that a fragmented trade union movement, with little or no coordinated leadership from the ICTU, continued its strategy of wage militancy in core strategic sectors of the economy (Hardiman, 1988). Unemployment soared and public expenditure on social policy increased by over $200 \%$. The government responded by cutting social welfare payments and raising income taxes. This provided the political conditions for the ICTU to organize unprecedented mass protests against the government's tax regime. These were followed by a series of mass demonstrations initiated by the Dublin Congress of Trade Unions aimed at a tax-strike, leading to one of the largest public mobilizations against an elected government in the history of the Irish state. The ICTU emerged as a central player in mobilizing public opinion against austerity. This meant that trade unions were making fiscal adjustment a highly salient electoral issue. These protests and a series of wildcat strikes aimed at pay increases put unprecedented pressure on the Labour party, which subsequently pulled out of government in 1986 over the issue of budgetary retrenchment (O’Leary, 1987).

In addition to the political instability imposed on the Fine Gael-Labour government by trade unions, there was also significant industrial unrest directed at employers. From 1970 to 1980 roughly 600000 days were lost annually to industrial action (Labour Relations Commission Annual Report, 2009). From 1980 to 1990, there were about 400000 days lost, which is one of the highest levels recorded in the OECD at the time; this came to a halt after 1987 (Roche, 2009). It was this disruptive capacity that induced the newly elected Fianna Fail government in 1987 to reject the approach of Fine Gael and seek a centralized political deal with ICTU. This was particularly important after the 1987 election, which resulted in a significant shift in 
urban working-class support towards Fianna Fail (Laver et al., 1987). The government needed the ICTU to get a fragmented union movement to accept wage restraint in order to generate the stability for an export-led economic recovery based on attracting foreign direct investment, particularly in the aftermath of the 1986 currency devaluation. But trade unions would only change their preference for wage militancy and industrial unrest if they were granted political access to influence the fiscal policy of the state. ${ }^{4}$

The new Fianna Fail Prime Minister, Charles Haughey, negotiated a 3 year national tax-based incomes policy with the ICTU in late 1987. The deal, named after the FF election manifesto, Programme for National Recovery (PNR), was underpinned by the 1986 National Economic and Social Council (NESC) report, Strategy for Development. This report, previously ignored by the FG government, argued that the Irish crisis was a direct outcome of a divergence in monetary, fiscal and wage policy. The advice to Fianna Fail was that if Ireland wanted to mirror the success of other small open economies in Europe (specifically citing the Netherlands, Austria and Sweden) then it was necessary to adopt an integrated and coordinated response to the crisis with the ICTU (Culpepper, 2008; Regan, 2010). From the perspective of the government, a centralized deal would shift trade unions away from 'protesting in the street' and into a problem-solving process of 'strategic economic management'. This is what occurred under the PNR in 1987, followed by the Programme for Economic and Social Progress (PESP) in 1990.

Fianna Fail recognized that the trade union movement was more than a narrow lobby group and had the political capacity to derail the government's weak electoral mandate. This is because the ICTU was in a position to mobilize popular consent among its affiliated unions, which represented over half the workforce, to provide support for government austerity while solving the problem of wage inflation. Haughey negotiated the PNR and PESP with trade union leaders in full knowledge that the political deals would be put to a national referendum among the 60 affiliated trade unions spanning the public and private sector. ${ }^{5}$ The main unions in the ICTU put the PNR and six subsequent national wage agreements to an internal democratic vote (Baccaro and Simoni, 2008). All passed. This process of institutionalized pacting-ended trade union militancy, enhanced the authority of the ICTU as a negotiating partner and provided unprecedented political legitimacy to a weak government pursuing fiscal retrenchment. Mobilizing democratic consent across the public and private sectors while helping to solve the problem

\footnotetext{
${ }^{4}$ Interview with Peter Cassells, General Secretary Irish Congress of Trade Unions (ICTU) (1989-2001). ${ }^{5}$ Interview with Bertie Ahern, Minister for Labour at the time, and subsequently Prime Minister (19972008).
} 
of wage restraint provided the carrot that led Fianna Fail to incorporate trade unions into public policymaking.

Industrial relations conflict, inflation and the loss of competitiveness associated with free-for-all wage bargaining compelled the FF government to centralize collective bargaining (Roche, 2009). The process of internal referenda ensured that the ICTU delivered their side of the bargain: national wage restraint and industrial peace. In return they got a seat at the table to implement government policy. This trade union influence was reflected in the establishment of the Central Review Committee (CRC), the executive wing of social partnership, specifically set-up to monitor the implementation of the PNR and PESP agreements. The CRC reported directly to the Prime Minister on a quarterly basis, providing the ICTU with unprecedented access to the corridors of government power and marking a fundamental change in how the state negotiated with trade unions. Trade unions were now publicly promoted as 'national problem solvers.'

What the ICTU could offer government during this period was stability. It could refrain from industrial action, negotiate reform and get its members to comply with wage restraint through a process of internal referenda. Second, the ICTU could forebear from mobilizing public opinion against government cuts in public expenditure. But both of these power resources (carrot and stick) were dependent upon ICTU having the legitimacy to be considered a representative of all working people. Trade unions did not consider that a narrowing of their membership to the public sector was a problem because they thought social partnership was now the default position of Irish politics and policymaking.

\subsection{The Eurozone crisis and the exclusion of trade unions from policymaking}

From 2008 to 2009 an FF minority government under the Prime Minister Brian Cowen eviscerated social partnership in Ireland and unilaterally cut public-sector pay twice, followed by legislation to cut the minimum wage and deregulate collective bargaining (Regan, 2012, 2013). In response the ICTU attempted to mobilize public opinion against government austerity by organizing a 1-day work stoppage. The strategy backfired when a vociferous mass media campaign was launched portraying trade unions as a public-sector cartel holding the government ransom (Roche, 2013). An analysis of opinion and editorial commentary in the print media during the final quarter of 2009 concluded that nearly $90 \%$ of press coverage

\footnotetext{
${ }^{6}$ Interview with Padraig O'hUiginn, secretary general to the Prime Minister (1986-1992); the same point was reiterated in interviews with subsequent secretary-generals, particularly Dermot McCarthy $(2000-2011)$.
} 
was 'anti-union' (ICTU, 2010). Unlike 1987-1992, trade unions were now considered a public-sector interest group, lobbying government in defence of 'overpaid bureaucrats' and 'labor market insiders.'

The weakened ability of Irish trade unions to engage in both wage militancy and public opinion mobilization is intimately bound up with a narrowing of their membership and the associated decline in collective bargaining coverage, which collapsed from approximately $70 \%$ in 1981 to $44 \%$ in 2010 (Regan, 2012). In turn this can be traced to a decline in the strategic importance of unionized employers in domestic industries. From 1981 to 1987 most of the export-sectors in the Irish economy included Irish firms with unionized employers and employees (Hardiman, 1988). The era of US led high-tech FDI had not yet arrived. These unionized firms had a close relationship with the semi-state commercial sectors and were organized into two different employer associations: the CII and the FUE. These were subsequently merged to form the Irish Business and Employers' Confederation (IBEC), in order to facilitate social partnership with the ICTU and government.

The PNR and PESP agreements had covered over 70\% of the workforce. By 2008 collective bargaining coverage in Ireland had declined to less than 44\%, the third lowest in the Eurozone after Estonia and Slovakia (Visser, 2009). Whereas in the mid-1980s more than 400000 days were lost to strike action, by 2008 this figure had dropped to 26000 . Remarkably, in the midst of the structural adjustment programme adopted in the wake of the crisis, there were only eight strikes in 2011, with fewer than 3700 days lost to industrial action. This is the lowest ever recorded in Ireland. Overall trade union density had declined to $31 \%$, a figure that masks a steeper decline and significant variation across the private and public sectors. In the public sector, overall density remains just under $80 \%$. Aggregate density in the private sector has fallen below $22 \%$. In this context employers and government have nothing to fear from trade unions. From the perspective of government, centralized collective bargaining is no longer considered necessary for solving the problem of wage restraint.

But the narrowing of collective bargaining coverage does not alone explain why Irish governments no longer need the ICTU. The Fianna Fail government introduced two public-sector pay-cuts from 2008 to 2010 despite trade union density rates in the public sector remaining constant since the late 1980s. This was justified by an internal report by the Department of Finance that blamed the asymmetric influence of social partnership for a decline in wage competitiveness, pro-cyclical taxes and increased public expenditure post-2002 (Regling and Watson, 2010). The Fianna Fáil government accepted this report's recommendation and chose to act unilaterally because no union affiliated to ICTU would be able to ballot

\footnotetext{
${ }^{7}$ Interview with Department of Public Expenditure and Reform.
} 
their members on pay-cuts. ${ }^{8}$ This removed the legitimizing effect of internal democratic ballots within unions for government: the NESC was sidelined, social partnership committees shut down and parliamentary subcommittees re-emerged as the main arena of decision-making within government. Trade unions were now considered part of the problem, not the solution.

During 2009-2011 public opinion turned even further against trade unions when it emerged that many union leaders were earning CEO-type salaries. This was followed by accusations of corruption in the Irish vocational and training agency and 'misplaced' internal SIPTU training funds. Internal feuds began to open up between public-sector unions representing high earners and those representing the 24/7 'Frontline Alliance' (healthcare and defence workers). During two anti-austerity protests in 2009 the leadership of the ICTU and SIPTU were booed off stage. The term 'trade union' had become shorthand for 'public sector cartel' in much of the print and broadcast media (Irish Times, 2010, 2013). But it was the close alignment of trade union leaders with the public policies of Fianna Fáil—which suffered a historic defeat in the 2011 elections, losing over 60 seats in parliament-that finally killed off the legitimizing effect of social partnership for politicians in Ireland.

The outcome of all this is that the ICTU has lost the legitimacy to be considered a social partner by the state. Between 2007 and 2010 public distrust in trade unions increased by a staggering 21 percentage points (from 32 to $53 \%$ ), the sharpest increase of all EU member-states. Since 2011 the newly elected FG-Labour government has chosen to continue the path of only negotiating with individual public-sector unions on a bilateral basis through the Department of Finance.

\section{The rise and fall of social partnership in Italy}

In the early 1990s, Italy faced pressing problems of controlling labour costs and reducing public spending. Its political party system collapsed in the wake of the Tangentopoli scandals, and a series of technocratic governments ruled the country and adopted significant reforms of the political economy. Unions were integral parts of strategies of reform involving wage restraint and public spending on pensions. In the industrial relations arena, unions were the preferred negotiating partners of the employers' association, which wanted to bring plant-level militancy and wage drift under control. In pension reform, a new government of the right, led by Silvio Berlusconi, tried to reform the pension system without unions and was brought down in part over the issue. One year later, another technocratic

\footnotetext{
${ }^{8}$ Even if trade union leaders had accepted pay cuts they would not have been able to get their membership to democratically vote on and accept this. Simultaneously, trade union leaders were aware that there was no appetite for strike action among their members (interview with Jack O'Connor, President of ICTU, 2009-2011).
} 
government—but one sympathetic to the left—passed pension reform by making unions an integral part of the policymaking process.

The first significant reason unions played this prominent role in both negotiations was because of the costs they could impose on employers and on governments if they were excluded. The Italian wage negotiations of the early 1990s were about how to replace the scala mobile with some sort of sectorally bargained system that would allow employers to avoid plant-level wage drift and thus improve their international competitiveness (Culpepper, 2008). Wage drift was a threat because local employers feared the capacity of organized workers to use their shop-floor power to demand wage top-ups. Unions themselves were challenged at the local level by more radical organizations, the COBAS (Rhodes, 1998). Italian employers wanted to sign deals with national unions, based on an agreed criteria of international competitiveness, in order to protect firms from these pressures.

The deal itself was contested within the union movement, both by local rivals and within the militant wing of the larger union, the CGIL (Simoni, 2010). As emphasized by Baccaro (2002), the main Italian unions used a procedural device to reaffirm their own legitimacy in striking the deal: they put it to a binding vote of union members. The union leaders won their gamble, reinforcing themselves by showing that the deal they had negotiated was democratically supported within the union movement. They were strengthened vis-à-vis their competitors, but also their centrality to the process of wage negotiation was reaffirmed to employers and to political actors.

Proof of the revitalized power of the Italian trade unions came in 1994, when the newly elected government of Silvio Berlusconi tried to introduce a unilateral reform of the pension system, which included an attack on seniority pensions, a hot button issue for trade unions. In response, the unions were able to organize a nationwide demonstration against the reform that forced the Berlusconi government to withdraw the measure, and shortly thereafter to resign. Their ability to mobilize broad social protest thus turned the unions into effective veto players in the pension negotiations of 1994 (Graziano and Jessoula, 2011).

In 1995, a technocratic government came to power led by Lamberto Dini, who had served as Finance Minister under the previous Berlusconi government. In sharp contrast to the exclusionary negotiating style of the previous government, 'the ensuing negotiations took the union scheme as their starting point', and 'the trade union representatives participated informally in each stage of the drafting of the Government bill' (Regalia and Regini, 1998, p. 493; Antichi and Pizzuti, 2000, p. 90). This reform achieved the goals of the previous government, but unions introduced long phase-ins - which both protected their members in the short-run, and gave those members a reason to vote for the compromise reform plan. 
And it is at this point is where union involvement comprised not only the threat of political harm to the government, but also the positive capacity to mobilize consent among its members to solve government problems. As in the earlier reform of industrial relations system, the measure was put to a vote of workers. Because unions had designed the reforms with an eye to persuading militant insiders-a perspective the government would not likely have included on its own (Culpepper, 2002) - it was able to campaign among these workers to get them to approve the bill. This ratification mechanism, which again shored up the internal support of the unions (Baccaro, 2002), was of direct benefit to the government. It was able to pass a substantial pension reform, which knowledgeable observers called 'one of the most radical reforms in the history of the Italian welfare state' (Regini and Regalia, 1997).

There is no doubt that Italian unions were effective veto players in the major moments of economic policy reform in the 1990s. This veto power allowed the unions to impose costs on the economy through strikes and costs on the government through protests, when governments tried to ignore them. Yet the story of the rebirth of social partnership in Italy in the 1990s is not merely a function of this deterrent power. It is also a function of the valuable capacities that unions were able to bring to the negotiating table once they worked with the government. In short, they offered the ability to help the government design policies in such a way that it could find a supportive majority within a divided workforce. This problem-solving capacity was harder for state actors to replicate on their own. Moreover, once the reform was agreed with the government, the democratic voting mechanisms employed by the unions proved a powerful tool to help them mobilize support for the agreement. The unions did indeed protect insider privileges in order to get the Italian pension reform passed. But they nevertheless helped design a policy that would resolve a long-standing problem facing the Italian welfare state.

\subsection{The government of Mario Monti and the exclusion of unions from policymaking}

The first technocratic government since that of Lamberto Dini in 1995 assumed power late in 2011 under the leadership of Mario Monti and the under the cloud of the Euro crisis. Like Dini, Monti succeeded Silvio Berlusconi as prime minister, whose centre-right coalition was widely perceived as incapable of halting the growing spreads between the interest rates paid on Italian and German government bonds, and thus sustaining Italian membership of the Euro. Monti came to power with a mandate to reform social and labour market policy to make Italy once again competitive in international markets (Pasquino and Valbruzzi, 2012).

Yet the union movement faced by the Monti government was of a substantially different character than the one that that had helped pilot reforms of the Italian 
social model in the 1990s. It was weaker on two fronts. First, it was much more internally divided between the big three unions (CGIL, UIL and CISL). While these unions had worked closely together in the 1990s, right-wing governments had driven a wedge between the largest group, the CGIL, and the two more moderate unions, which agreed to two social pacts that the CGIL did not sign in 2002 and 2009 (Simoni, 2010). Compared with the united unions that had mobilized workers to support difficult reforms through direct democracy in 1993 and 1995, the concertation of unions was much more divisive than in the earlier periods, and therefore they were not in a strong position to help solve government problems.

These divisions among union confederations exacerbated their declining power at the shop floor, which is tied to declining membership. Union density has been in decline since the late 1970s; between 1993 and the 2007 it continued to fall further, from 39 to $33 \%$ of the workforce (Visser, 2009). Moreover, this overall density masks differences across generations and across the economy. Survey data by Baccaro and Pulignano (2011) suggest that in 2008 union density for the private sector was only $19 \%$, and the density among the 18-34 age group was also only $19 \%$. This is a fragile basis of representation from which to demand a seat at the table with policymakers.

This was the industrial relations background against which the Monti government assumed power in November 2011. Its first act of austerity was a plan called Salva Italia, much of whose cost-cutting came through an ambitious pension reform. The reform completed the move to a defined contribution system that had begun in 1995, and it raised the retirement age for women in the private sector to 62 , which is forecast to increase further until it equals that of men (67) in 2018. The bill also unlinked pensions above the level of $€ 1400$ per month from inflation. Procedurally, the unions were informed of the content of the reform, but even these meetings took place in bilateral fashion, with the government representative meeting individually with each union, rather than jointly. Concertation was out; pluralism was in. The three divided union confederations were able to unite their forces and call for a public-sector strike in protest at the pension reform, but this changed nothing in the pension reform and did little apparent harm to the government.

Clearly, the union stick was not all that threatening in the case of the pension reform. What about the carrot of problem-solving? Without unions capable of working with policymakers, governments are likely to make politically costly mistakes, as indeed happened in the case of the Monti government's pension reforms. Because of the changed retirement thresholds, workers who had previously taken early retirement became suddenly ineligible for pensions. Those who had left the workforce but been left behind by the changing rules of the pension system came to be called the esodati: the exiled ones. The technocratic government vowed to cover the esodati, estimating their number at 65000 . Union estimates of the 
exiled ones, though, were substantially higher, about 400000 - and the figure of 390000 was eventually ratified by the state's social security agency in June, 2012 (Repubblica, 2012). The Monti government got it wrong, while the unions got it right. The question of how to deal with the exiled ones, and their number, continued to dog the technocratic government. In October 2012, the State General Accounting Department rejected the bill on the esodati as having manifestly insufficient financial provision for those it promised to cover (Corriere della Sera, 2012). The exiled ones were insiders, yes_-but the government's inability to provide for their plight was a politically damaging error, one that union problem-solving capacity, had it been available, may well have helped to avoid.

The pattern of non-consultation first adopted in the pension reforms continued in the Monti administration's attempted reform of labour market policy. The government proposed to weaken the protections afforded against unfair dismissal embedded in article 18 of the labour code. Article 18 requires all firms having fewer than 15 workers to reinstate a fired worker in the case labour court decides they have been wrongfully terminated. Companies view the courts as sympathetic to workers, and thus consider the provision an effective block on firing. The Monti government negotiated with labour unions for 2 months in early 2012 and then said it would carry on without the agreement of the unions.

Unlike in the case of the pension reform, the Italian unions were this time able to use protests as a tool to rally public opinion against the change of article 18. Following large street protests, the government then retreated, allowing labour courts to reinstate workers fired for implausible economic grounds. Unions opposed even this weakened reform, which they viewed as a slippery slope to neoliberalism. But there is no doubt that the protests around article 18 forced the government to change course. Does this instance of successful protest not belie our claim that unions do not have a stick to threaten the government?

On the contrary, the article 18 protests are consistent with our argument that unions cannot strike fear into the government, and can be generally treated as one private interest group among many. These protests were not 'the beginning of the end' for the Monti government. Instead, they were tactical reversals-essentially equivalent to the reversals that organized taxi drivers, pharmacists and lawyers had each extracted from the government when it attempted to liberalize those professions in January 2012. In each case, the attempt to open the closed groups to competition-led pressure groups to organize strikes and to mobilize support from the political parties associated with them (in the case of taxi drivers and pharmacists, the centre-right; in the case of labour unions, the centre-left).

Technocratic governments are still supported by political parties, and these parties are able to undermine such governments when their core constituencies protest. Yet the ability to make such demands falls well short of precipitating the fall of a government, as we could describe the strike against the Berlusconi in 
1994. And indeed, the Italian labour unions acquired no momentum as a result of the article 18 protests, which they could later mobilize to achieve other policy gains on behalf of working people. By 2012, Italian trade union confederations had moved from being a veto player on all major social reforms - the position they occupied in the mid-1990s - to being one pressure group among others. The major difference between them and the taxi drivers was just a few extra members.

\section{Discussion}

In both Ireland and Italy, weak governments that faced significant challenges of economic adjustment in the past worked with unions in order to be able to develop their policies of reform. During the recent Eurozone crisis, they have emphatically rejected the utility of using social pacts with unions to develop their reforms, as illustrated by the quotations from Mario Monti and Brian Lenihan with which this article began. We have attributed this choice to a decline of two parallel capacities: striking fear into government and the ability to solve government problems through mobilizing support for politically difficult reform packages. With neither carrot nor stick to brandish towards the government, unions in Ireland and Italy have been reduced to the role of being a narrow interest group like any other.

One alternative explanation we have not considered until now deserves consideration: that the exclusion of unions was a political choice, because the political leaders in Ireland and Italy simply disliked working with unions. Hamann and Kelly (2007) have in the past pointed to the political dimension of social partnership; it is a calculus that parties make with an eye to the next polling day. Such an argument cannot be behind the choices of Monti and Cowen to eschew social partnership, though, since the choice to exclude unions meant they had to take the full weight of electoral opprobrium for harsh reform programmes. Both faced crushing electoral rejection after their time in office.

The ideological objection cannot be entirely dismissed, however. Mario Monti has never favoured negotiation with unions. And the Ministry of Finance in Ireland consistently questioned social partnership as a way to solve policy problems. However, our argument about the power of unions to cause governments harm is one that extends to parties of the right as well as to the left. Berlusconi's government tried to exclude unions in its 1994 pension reform and was defeated in the wake of this decision. In other words, there were politicians in the 1990s who did not favour working with unions for ideological reasons. But the high cost unions could impose on these governments made this an unpalatable option. In 2012, there was no similar cost that had to be paid, as a result of the weakening of the union movement in Ireland and Italy. 
Social pacts in an earlier period were adopted primarily by countries that lacked the infrastructure of institutionalized negotiation characteristic of the northern European CMEs. Some analyses of social pacts have included agreements between the social partners in the Netherlands (Rhodes, 1998) or Finland (Avdagic, 2010). We do not expect our findings to hold in these cases, should they have economic troubles of the sort facing southern Europe and Ireland in the Euro crisis. Finland enjoys roughly $70 \%$ union density. In the Netherlands, the constitutionally entrenched power of works councils provides strong microfoundations for the periodic macro-bargaining that emerges in the case of Dutch social pacts (Hancké and Rhodes, 2005; Culpepper, 2011). Our argument is restricted in scope to the countries that do not enjoy such institutional arrangements. These are, of course, precisely the countries that seemed to benefit so much from the reform capacities generated by social pacts 15 years ago, during the optimistic preparation for the EMU.

These theoretical claims about the role of unions in Ireland and Italy may have wider application, and call for further research; particularly, the question as to whether previous social pacts have themselves contributed to a decline in legitimacy. The Dutch and Finnish cases suggest this may not be the case. Despite the extensive use of social pacting in these countries, Finnish public distrust in unions was only $27 \%$ in 2010 , and only $30 \%$ of people polled expressed distrust in Dutch unions. Social pacts do not necessarily cause public trust in unions to weaken, as the experience of these countries shows. Instead, it is probable that protracted and nakedly self-interested insider behaviour leads to the rise in public distrust. Hence, it is likely the content of the deal that matters for future union legitimacy.

Union economic and political power-the ability to cripple production or to call mass demonstrations in a capital that shake the government-has always been part of the arsenal of labour negotiation. We have argued that this industrial and political strength, or what we have called the stick of union power, has the same sources as the more reform-friendly capacity to mobilize consent to solve government problems. Both are aspects of the underlying legitimacy of unions as representing a broad interest in society: the interest of those who sell their labour in the service of economic production. It is on the basis of this legitimacy that unions have claimed to be the privileged interlocutor of employers in the private sector and state representatives more broadly. When that legitimacy goes, both the sharpness of the stick and the sweetness of the carrot are degraded.

Our findings are speculative, based on what we have observed in two countries. But the interaction between union legitimacy, an increasingly narrow membership, and elite and mass opinion seems to us a crucial and underexplored part of the debate about the political economy of contemporary capitalism today. Social pacts once appeared to provide a way for a broad societal input to be rallied behind stringent reform plans, even in countries without the institutions for 
neocorporatist negotiation. The most recent episode of Eurozone reform has shown that the governments no longer feel that unions are worth the trouble of bringing into privileged negotiation. They can be treated as just one interest group among many.

\section{References}

Antichi, M. and Pizzuti, R. (2000) 'The Public Pension System in Italy'. In Reynaud, E. (ed) Social Dialogue and Pension Reform, Geneva, International Labour Office, pp. 81-96.

Armingeon, K. and Baccaro, L. (2012) 'The Sorrows of Young Euro'. In Bermeo, N. and Pontusson, J. (eds) Coping with Crisis: Government Reactions to the Great Recession, New York, Russell Sage, pp. 162-198.

Avdagic, S. (2010) 'When Are Concerted Reforms Feasible? Explaining the Emergence of Social Pacts in Western Europe', Comparative Political Studies, 43, 628-657.

Baccaro, L. (2002) 'The Construction of 'Democratic' Corporatism in Italy', Politics and Society, 30, 327-357.

Baccaro, L. and Howell, C. (2011) 'A Common Neoliberal Trajectory', Politics and Society, 39, 521-563.

Baccaro, L. and Lim, S.-H. (2007) 'Social Pacts as Coalitions of the Weak and Moderate: Ireland, Italy and South Korea in Comparative Perspective', European Journal of Industrial Relations, 13, 27-46.

Baccaro, L. and Pulignano, V. (2011) 'Employment Relations in Italy'. In Bamber, G., Lansbury, R. and Wailes, N. (eds) International and Comparative Employment Relations, 5th ed., New York, Sage.

Baccaro, L. and Simoni, M. (2008) 'Policy Concertation in Europe: Understanding Government Choice', Comparative Political Studies, 41, 1323-1348.

Corriere della Sera. (2012, 9 October) 'Ddl Esodati: “Copertura Insufficiente”.

Culpepper, P. D. (2002) 'Powering, Puzzling, and 'Pacting', Journal of European Public Policy, 9, 774-790.

Culpepper, P. D. (2008) 'The Politics of Common Knowledge', International Organization, 62, $1-33$.

Culpepper, P. D. (2011) Quiet Politics and Business Power, New York, Cambridge University Press.

Graziano, P. R. and Jessoula, M. (2011) 'The Italian Trajectory of Recent Welfare Reforms'. In Graziano, P. R., Jacquot, S. and Palier, B. (eds) The EU and the Domestic Politics of Welfare State Reforms, New York, Palgrave Macmillan, pp. 148-174.

Hall, P. A. and Soskice, D. (eds) (2001) Varieties of Capitalism, New York, Oxford University Press.

Hamann, K. and Kelly, J. (2007) 'Party Politics and the Reemergence of Social Pacts in Western Europe', Comparative Political Studies, 40, 971-994. 
Hancké, B. and Rhodes, M. (2005) 'EMU and Labor Market Institutions in Europe', Work and Occupations, 32, 196-228.

Hardiman, N. (1988) Pay, Politics, and Economic Performance in Ireland, 1970-1987, Oxford, Clarendon Press.

Hassel, A. (2006) Wage Setting, Social Pacts, and the Euro, Amsterdam, Amsterdam University Press.

Hassel, A. (2009) 'Policies and Politics in Social Pacts in Europe', European Journal of Industrial Relations, 15, 7-26.

ICTU (2010) 'Analysis of Op/Ed Coverage in the Irish Newspapers', Dublin, ICTU (manuscript).

Labour Relations Commission Annual Report (2009) Dublin, 6 June 2013. Available at http://www.lrc.ie/viewdoc.asp?DocID=751\&m=7.

The Irish Times (2010, 25 January) 'Searching for Answers in the Wake of Collapsed Partnership'.

The Irish Times (2013, 27 February) 'Union Solidarity the First Victim of Croke Park II'.

Laver, M., Mair, P. and Sinnott, R. (1987) How Ireland Voted: The Irish General Election 1987, Dublin, Poolbeg.

Molina, O. and Rhodes, M. (2007) 'Industrial Relations and the Welfare State in Italy: Assessing the Potential of Negotiated Change', West European Politics, 30, 803-829.

Murphy, G. and Hogan, L. (2008) 'Fianna Fáil, the Trade Union Movement and the Politics of Macroeconomic Crises, 1970-82', Irish Political Studies, 23, 577-598.

Natali, D. and Rhodes, M. (2004) 'Trade-Offs and Veto Players: Reforming Pensions in France and Italy', French Politics, 2, 1-23.

O'Leary, B. (1987) 'Towards Europeanisation and Realignment?', West European Politics, 10, $455-465$.

Palier, B. and Thelen, K. (2010) 'Institutionalizing Dualism', Politics and Society, 38, 119-148.

Pasquino, G. and Valbruzzi, M. (2012) 'Non-Partisan Governments Italian-Style', Journal of Modern Italian Studies, 17, 612-629.

Psimitis, M. (2011) 'The Protest Cycle of Spring 2010 in Greece', Social Movement Studies, 10, 191-197.

Regalia, I. and Regini, M. (1998) 'Italy: The Dual Character of Industrial Relations'. In Ferner, A. and Hyman, R. (eds) Changing Industrial Relations in Europe, Malden, MA, Blackwell Publishers, pp. 459-503.

Regan, A. (2010) 'Does Discourse Matter in the Formation and Consolidation of Social Pacts?', Critical Policy Studies, 4, 250-277.

Regan, A. (2012) 'The Political Economy of Social Pacts in the EMU: Irish Liberal Market Corporatism in Crisis', New Political Economy, 17, 465-491.

Regan, A. (2013) 'The Impact of the Eurozone Crisis on Irish Social Partnership', ILO Working Paper 49. 
Regini, M. (2000) 'Between Deregulation and Social Pacts', Politics and Society, 28, 5-33.

Regini, M. and Regalia, I. (1997) 'Employers, Unions and the State', West European Politics, 20, 210-230.

Regling, K. and Watson, M. (2010) A Preliminary Report on The Sources of Ireland's Banking Crisis, Dublin, Stationery Office.

Repubblica (2012, 11 June) 'Esodati, l'Inps: 'Possibili 390mila”'.

Rhodes, M. (1998) 'Globalization, Labour Markets, and Welfare States: A Future of: “Competitive Corporatism?”. In Rhodes, M. and Mény, Y. (eds) The Future of European Welfare: A New Social Contract?, London, Macmillan, pp. 178-203.

Roche, W. K. (2009) 'Social Partnership: From Lemass to Cowen', Economic and Social Review, 40, 183-205.

Roche, W. K. (2013) 'Austerity without Solidarity: Industrial Relations, Employment and Welfare in the Irish Crisis', Paper Prepared for Conference on Varieties of Capitalism and Responses to the European Employment Crisis, University of Denver, Colorado, 1-2 June 2012.

Simoni, M. (2010) 'Labour and Welfare Reforms: The Short Life of Labour Unity'. In Mammone, A. and Veltri, G. A. (eds) Italy Today. The Sick Man of Europe, London, Routledge, pp. 229-242.

Visser, J. (2009) ICTWSS Database on Institutional Characteristics of Trade Unions, Wage Setting, State Intervention and Social Pacts in 34 Countries Between 1960 and 2007, Amsterdam, Amsterdam Institute for Advanced Labour Studies. 